\title{
Aspirasi Benda Asing Paku dengan Komplikasi Atelektasis Paru dan Aspirasi Benda Asing Jarum Pentul Tanpa Komplikasi
}

Novialdi, Fachzi Fitri, Histawara Subroto

\begin{abstract}
Abstrak
Aspirasi benda asing bronkus adalah masalah yang sering pada anak-anak dan merupakan masalah serius serta bisa berakibat fatal. Sebagian besar aspirasi benda asing di bronkus pada anak-anak karena kecenderungan memasukkan sesuatu ke mulut, pertumbuhan gigi molar yang belum lengkap, kurangnya pengawasan dari orang tua dan lain-lain. Aspirasi jarum pentul di bronkus biasanya terjadi pada wanita remaja muslim yang menggunakan jilbab. Benda asing tajam di bronkus harus segera dikeluarkan dalam kondisi dan peralatan optimal untuk mencegah komplikasi yang timbul. Komplikasi akibat aspirasi benda asing tajam yang paling sering berupa perforasi jalan nafas, trakeitis, bronkitis, jaringan granulasi, efusi pleura dan atelektasis. Tindakan bronkoskopi merupakan pilihan untuk ekstraksi benda asing tajam yang teraspirasi. Dilaporkan dua kasus aspirasi benda asing tajam di bronkus yaitu pada seorang anak laki-laki, berusia 6 tahun dengan aspirasi paku dengan komplikasi atelektasis paru dan seorang anak perempuan, berusia 14 tahun dengan aspirasi jarum pentul tanpa komplikasi yang telah berhasil diekstraksi menggunakan bronkoskopi kaku.
\end{abstract}

Kata kunci: benda asing tajam di bronkus, aspirasi paku, aspirasi jarum pentul, atelektasis, bronkoskopi kaku

\section{Abstract}

Bronchial foreign body aspiration is a common problem in children and it is a serious problem that can be fatal. Most of bronchial foreign body aspiration occur in children because of the tendency to put something into the mouth, the molar growth is not yet complete, the lack of supervision from parents and others situation . Aspiration of a pin in the bronchi usually occurs in adolescent Muslim women who wear headscarf. Sharp foreign bodies in the bronchi must be removed immediately and the optimal equipment to prevent complications. Complications due to sharp foreign bodies aspiration most often in the form of perforation, tracheitis, bronchitis, granulation tissue, pleural effusion and atelectasis. Bronchoscopy is the management for aspirated sharp foreign body extraction Reported two cases of a sharp foreign body aspiration is a boy, aged 6 year old with nail aspiration complication with lung atelectasis and a girl, aged 14 year old with aspirations of a pin without complications that have been successfully extract using rigid bronchoscopy. Arial 9 italic

Keywords: sharp foreign bodies in the bronchi, nail aspiration, pin aspiration, atelectasis, rigid bronchoscopy

Affiliasi penulis : Bagian THT-KL Fakultas Kedokteran Universitas Andalas

Korespondensi : Histawara Subroto, E-mail: histawara@gmail.com, Telp: 082388118234

\section{PENDAHULUAN}

Aspirasi benda asing adalah salah satu penyebab kesakitan dan kematian pada anak dibawah umur 6 tahun. Pada negara berkembang sekitar 300-600 anak pertahun dibawah 15 tahun meninggal karena aspirasi benda asing. ${ }^{1}$ Aspirasi benda asing lebih sering terjadi pada laki-laki dengan perbandingan antara laki-laki dan perempuan $2: 1 .^{2}$ Latifi $\mathrm{dkk}^{3}$ pada penelitiannya tahun 1994-2003 di Kosovo mendapatkan kejadian aspirasi benda asing pada laki-laki 107 kasus (59\%) dan perempuan 75 
kasus (41\%), kejadian umur 0-3 tahun sebanyak 124 kasus (68\%), umur 4-7 thn sebanyak 36 kasus (20\%). Pada penelitian Cataneo yang dikutip dari lativi dkk mendapatkan kejadian pada laki-laki 94 kasus (57\%), dan pada perempuan 70 kasus (43\%), dan $84 \%$ ditemukan pada usia dibawah 16 tahun.

Benda asing teraspirasi lebih sering pada anak-anak karena anak-anak mempunyai kebiasaan meletakkan atau menggigit benda di mulut sambil bermain/berlari, dan pada saat tertentu anak kurang diawasi orang tua. ${ }^{1,4-6}$ Beberapa faktor lain terjadinya aspirasi benda asing pada anak-anak yaitu: a). Anakanak sedang mengekplorasi lingkungan sekitarnya dengan seringnya meletakkan sesuatu di mulut sambil bermain dan berlari, b). Pertumbuhan gigi molar anak yang belum lengkap sehingga proses mengunyah belum sempurna, c). Anak-anak belum dapat membedakan yang dapat dimakan dengan yang tidak, d). Koordinasi antara menelan dan penutupan glotis yang belum sempurna. ${ }^{7}$

Saat aspirasi terjadi, benda asing masuk melalui rima glotis yang sedang terbuka, sehingga masuk ke dalam trakea dan bronkus. Pada orang dewasa benda asing cenderung tersangkut pada bronkus utama kanan karena lebih segaris lurus dengan trakea dan posisi karina yang lebih besar. Sampai umur 15 tahun sudut yang dibentuk bronkus dengan trakea antara kiri dan kanan hampir sama, sehingga pada anak-anak, frekuensi lokasi tersangkut benda asing hampir sama kejadian antara bronkus utama kiri dan kanan. Lokasi tersangkut benda asing juga dipengaruhi posisi saat terjadi aspirasi. ${ }^{8}$ Iskandar pada laporannya di bagian THT FKUI/ RS Cipto Mangunkusomo selama 4 tahun dari Januari 1990 Desember 1993 mendapatkan 70 kasus aspirasi benda asing di traktus trakeobronkial. Lokasi benda asing tersering $(62,86 \%)$ di bronkus utama kanan. ${ }^{2}$

Benda asing yang teraspirasi dikelompokkan menjadi dua kategori yaitu organik dan anorganik. Benda asing organik yang sering pada anak adalah kacang sedangkan benda asing anorganik yang sering dijumpai adalah koin, peniti dan bagian mainan kecil.5,6,9,10 Sedangkan, Taksande $\mathrm{dkk}^{9}$ membagi benda asing teraspirasi menjadi: 1). Benda asing non iritasi seperti plastik, kaca, logam, yang terkadang tidak menggangu aliran udara sehingga jarang menimbulkan gejala klinis dalam waktu lama, dan 2). Benda asing iritasi seperti sayuran, biji-bijian, kacang, merupakan benda asing yang mudah menimbulkan reaksi inflamasi, edema mukosa trakeobronkial sehingga menyebabkan obstruksi total saluran nafas.

Jenis benda asing yang teraspirasi bervariasi dari masing-masing negara tergantung pendidikan, sikap orang tua, kebiasaan makan, ketersediaan jenis benda asing yang berpotensi mengancam jiwa. Sebagian besar benda asing yang teraspirasi adalah benda organik, yaitu kacang 127 (62\%), sedangkan benda yang terbuat dari logam 12(1,2\%). ${ }^{3,11}$ Aspirasi jarum pentul biasanya terjadi pada wanita remaja muslim yang menggunakan jilbab. ${ }^{12}$ Benda asing anorganik seperti jarum tidak bersifat higroskopis, sehingga reaksi jaringan lebih sedikit dibandingkan dengan benda asing organik, tetapi benda asing tajam lebih berbahaya karena berpotensi menimbulkan perforasi jalan nafas. ${ }^{11,13}$

Diagnosis aspirasi benda asing di bronkus ditegakkan berdasarkan anamnesis, pemeriksaan fisik, pemeriksaan radiologi dan pemeriksaan bronkoskopi. ${ }^{14-16}$ Anamnesis yang baik, pemeriksaaan fisik dan pemeriksaan radiologi penting untuk menegakkan diagnosis aspirasi benda asing pada saluran nafas. 5,6,10 Kapan terjadinya aspirasi perlu ditanyakan karena erat kaitannya dengan prognosis. Benda asing yang sudah berada lama di saluran nafas, sering menimbulkan radang kronis dan jaringan granulasi. ${ }^{11,17,18}$

Gejala aspirasi benda asing terbagi dalam 3 fase yaitu :

\section{Fase awal}

Saat benda asing teraspirasi, batuk hebat secara tiba-tiba, rasa tercekik, rasa tersumbat di tenggorok, wheezing dan obstruksi nafas, dapat juga disertai adanya sianosis terutama perioral, kematian pada fase ini sangat tinggi.

2.Fase asimptomatik

Interval bebas gejala terjadi karena benda asing tersangkut pada satu tempat, dapat terjadi dari beberapa menit sampai berbulan-bulan setelah fase pertama. Lama fase ini tergantung lokasi benda asing, derajat obstruksi yang ditimbulkannya dan jenis benda asing yang teraspirasi serta kecenderungan benda asing untuk berubah posisi. 


\section{Fase komplikasi}

Telah terjadi komplikasi akibat benda asing, dapat berupa pneumonia, efusi pleura, atelektasis paru, abses dan hemoptisis. ${ }^{13,19}$

Aspirasi benda asing tanpa menimbulkan obstruksi akut akan menimbulkan reaksi tergantung dari jenisnya, organik atau anorganik. Aspirasi benda asing yang anorganik, jika tidak menimbulkan obstruksi, dapat asimptomatis pada waktu yang lama. ${ }^{6}$ Setelah benda asing masuk ke dalam bronkus terjadi fase asimptomatik selama 24 jam atau lebih, diikuti gejala pulmonum, hal tersebut bergantung pada derajat sumbatan bronkus benda asing. Benda asing organik menyebabkan reaksi inflamasi mukosa yang lebih berat dan jaringan granulasi dapat timbul dalam beberapa jam. Benda asing organik seperti kacang-kacangan dan biji-bijian bersifat menyerap air sehingga dapat mengembang, yang akan menambah sumbatan, obstruksi parsial dapat berubah menjadi total. Benda asing organik yang berada pada arah distal menyebabkan inflamasi kronik sehingga sering memerlukan reseksi paru. ${ }^{20}$

Pada pemeriksaan fisik dapat ditemukan tanda-tanda sumbatan jalan nafas dengan berbagai variasi gejala sesuai dengan lokasi benda asing, ukuran, derajat sumbatan, dan lamanya waktu aspirasi. ${ }^{7}$ Aspirasi benda asing biasanya tersangkut di 3 tempat yaitu laring, trakea dan bronkus. Benda asing di trakea jarang terjadi, hanya sekitar $10-20 \%$ dari seluruh benda asing di jalan napas, sedangkan lokasi yang tersering adalah pada bronkus (80$90 \%) .{ }^{21}$ Benda asing di bronkus dapat menyebabkan terjadinya tiga tipe obstruksi:

1.Obsruksi katup bebas (by pass valve obstruction).

2.Katup penghambat ekspiratori atau katup satu arah (check valve obstruction).

3.Obstruksi katup tertutup (stop valve obstruction). ${ }^{20,22}$

Penderita dengan benda asing di bronkus umumnya datang pada fase asimptomatik. Pada fase ini keadaan umum penderita masih baik dan foto torak belum memperlihatkan kelainan. Pada fase pulmonum, benda asing di bronkus utama atau cabang - cabangnya akan menimbulkan gejala batuk, sesak nafas yang makin lama semakin bertambah berat. Pada auskultasi terdengar ekspirasi memanjang dengan mengi dan dapat disertai demam. ${ }^{14-16,23}$ Gejala yang sering adalah batuk $68,3 \% .^{5}$ sedangkan pada penelitian Cataneo $\mathrm{JM}^{6}$ mendapatkan gejala batuk 112 kasus (68\%), rasa tercekik 90 kasus $(54,9 \%)$, dan sesak 47 kasus $(28,7 \%)$.

Pada setiap pasien aspirasi benda asing harus dibuat foto torak untuk mengetahui bentuk dan ukuran benda asing, lokasi serta komplikasi yang timbul. Pemeriksaan radiologi yang diperlukan adalah posisi antero-posterior, lateral dan bila perlu pemeriksaan fluoroskopi. ${ }^{24}$ Menurut Riple, Rontgen torak harus dilakukan pada kasus aspirasi benda asing ataupun yang diduga aspirasi benda asing, meskipun lebih dari $90 \%$ dari benda asing adalah radiolusen. $^{25}$ Peneliti lain mendapatkan adanya gambaran pneumonia 24 kasus $(13,1 \%)$, atelektasis 22 kasus (12\%), udara yang terperangkap 9 kasus $(4,9 \%)$, terlihat benda asing 5 kasus (2,7\%), gambaran normal 116 kasus $(63,7 \%) .{ }^{26}$

Rontgen torak yang diambil dalam waktu 24 jam pertama setelah kejadian aspirasi, biasanya menunjukkan gambaran normal. ${ }^{19}$ Benda asing radioopak dapat diidentifikasi dengan mudah, tetapi benda asing radiolusen dapat dikenal dari efek samping yang timbul pada paru seperti atelektasis, emfisema dan gambaran infiltrat. ${ }^{19,24}$ Benda asing kecil yang tidak menimbulkan sumbatan lumen bronkus pada saat inspirasi maupun ekspirasi tidak akan menimbulkan atelektasis atau emfisema, maka sebaiknya dibuat foto torak antero-posterior pada waktu inspirasi dalam dan ekspirasi. Gambaran radiologi benda asing yang tidak menimbulkan gejala sumbatan jalan nafas dapat menunjukkan gambaran pneumonia dan tidak sembuh dengan pengobatan antibiotik yang adekuat. ${ }^{23}$

Pada tahun 1895 Killian memperkenalkan bronkoskopi, dan 2 tahun kemudian yaitu tahun 1897 Killian berhasil mengeluarkan benda asing sepotong tulang pada bronkus. Di Amerika Algernon Coolidge Jr pada tahun 1899 adalah orang pertama pada rumah sakit Massachusetts yang melakukan bronkoskopi melalui trakeostomi dan mengeluarkan anak kanul trakeostomi pada bronkus seorang wanita 
berumur 23 tahun. Pada awal 1900 Chevalier Jackson mempelopori pembuatan alat-alat untuk endoskopi saluran nafas yang lebih praktis dan aman, fiber optik diperkenalkan tahun $1960 .^{6}$ Ada 2 macam bronkoskop :

a.Bronkoskop Kaku (Rigid bronchoscope)

b.Bronkoskop Serat Optik (Flexible bronchoscope) ${ }^{8}$

Bronkoskop kaku merupakan pilihan untuk ekstraksi benda asing yang teraspirasi pada anak, karena ventilasi lebih terjamin, lebih mudah untuk melakukan tindakan dan dapat mengatasi perdarahan. ${ }^{5}$

Prinsip penanganan benda asing di saluran nafas adalah mengeluarkan benda asing tersebut dengan segera dalam kondisi paling maksimal dan trauma yang minimal. Penentuan cara pengambilan benda asing dipengaruhi oleh beberapa faktor, misalnya : umur penderita, keadaan umum, lokasi dan jenis benda asing, tajam atau tidaknya benda asing dan lamanya benda asing berada di saluran nafas. Tidak ada kontraindikasi absolut untuk tindakan bronkoskopi, selama hal itu merupakan tindakan untuk menyelamatkan nyawa (life saving). Pada aspirasi benda asing organik yang menyebabkan sumbatan total, maka harus segera dilakukan bronkoskopi, bahkan bila perlu tanpa anestesi umum. ${ }^{8}$

Ada beberapa faktor yang menentukan keberhasilan penatalaksanaan benda asing di saluran nafas, antara lain tim yang berpengalaman, kerjasama yang baik antara operator dengan tim anestesi dan ketersediaan alat sesuai dengan kebutuhan. ${ }^{27}$ Bronkoskop kaku merupakan pilihan untuk ekstraksi benda asing di saluran nafas, disamping juga digunakan untuk diagnosis pada kasus kecurigaan benda asing. Pilihan memakai bronkoskop kaku atau fleksibel tergantung pada pilihan operator, lokasi benda asing dan usia pasien. ${ }^{6}$ Beberapa faktor yang mempengaruhi timbulnya penyulit bronkoskopi pada ekstraksi benda asing di saluran nafas, antara lain adalah faktor keadaan umum penderita, jenis, bentuk, ukuran, lokasi, dan posisi benda asing. ${ }^{16-18}$

Sesaat menjelang dilakukan bronkoskopi dibuat foto torak untuk menilai kembali letak benda asing. ${ }^{12,28}$ Dengan mempelajari lokasi lesi paru pada Rontgen foto torak, seorang endoskopis sebelumnya harus dapat mengidentifikasi sasaran endoskopi, ke arah segmen atau subsegmen paru. ${ }^{21,23}$ Komunikasi antara operator dengan dokter anestesi untuk menentukan rencana tindakan juga sangat penting. ${ }^{12,28}$ Penyulit pada penatalaksanaan benda asing di bronkus antara lain faktor penderita, lamanya benda asing teraspirasi, lokasi benda asing, kelengkapan alat, kemampuan tenaga medis dan paramedis dan anestesi yang terampil. ${ }^{19}$

Persiapan sebelum dilakukan bronkoskopi sebaiknya diketahui duplikat benda asing, kemudian dicoba dan dipelajari lebih dulu cara menjepit dan menarik benda asing dengan cunam yang sesuai. Bronkoskop dipilih sesuai dengan diameter lumen dengan berpedoman pada usia penderita akan dapat meningkatkan keberhasilan. ${ }^{8,24}$ Pemberian steroid dan antibiotika preoperatif dapat mengurangi komplikasi seperti edema jalan nafas dan infeksi. ${ }^{11,29,30}$

Komplikasi yang mungkin terjadi pada aspirasi benda asing di trakeobronkial berhubungan dengan benda asing sendiri dan tindakan bronkoskopi. Komplikasi akibat benda asing yang paling sering berupa infeksi paru seperti edema mukosa paru, trakeitis, bronkitis, jaringan granulasi, efusi pleura dan atelektasis. Komplikasi yang berhubungan dengan tindakan bronkoskopi (intra operatif) paling sering aritmia jantung, bronkospasme, edema laring, trauma pada gigi, bibir, gusi dan laring. ${ }^{19,29,31}$

Atelektasis adalah gangguan perkembangan paru yang disebabkan berkurangnya pertukaran udara perifer didalam paru. Seorang klinisi harus dapat membedakan mekanisme terjadinya atelektasis. Terdapat 3 mekanisme yang dapat menyebabkan atelektasis, yaitu 1). Peningkatan tekanan permukaan di dalam alveolus, 2). Kompresi parenkim paru akibat peningkatan dinding intratorak maupun ekstratorak paru, 3). Obstruksi jalan nafas yang menyebabkan berkurangnya pertukaran udara di alveolus. Diagnosis atelektasis berdasarkan gejala klinis, pemeriksaan fisik, pemeriksaan laboratorium, pemeriksaan radiologi dan bronkoskopi. Gejala klinis atelektasis pada anak-anak sulit dikenali karena tidak ada gejala spesifik yang muncul, sehingga keadaan atelektasis terkadang terlambat untuk diterapi. Gejala 
klinis dan pemeriksaan fisik atelektasis didapatkan adanya sesak nafas, batuk, riwayat tersedak, demam, retraksi dinding dada dan suara nafas paru yang melemah. Pada pemeriksaan radiologi dapat ditemukan gambaran opasifikasi, pergeseran mediastinum, elevasi diafragma, pergeseran fissure interlobaris dan silhouette sign. Bronkoskopi kaku pada kasus atelektasis dapat digunakan sebagai alat diagnostik maupun terapeutik, Bronkoskopi dengan tujuan terapeutik seperti ekstraksi benda asing, pengambilan plak mukus bronkus dan bronkoskopi lavage yang dilakukan bila didapatkan atelektasis dengan banyak sekret mukopurulen. Bronkoskopi diagnostik bertujuan untuk pengambilan sekret bronkus sebagai pemeriksaan kultur dan pemeriksaan biopsi jaringan terhadap kecurigaan atelektasis yang disebabkan oleh keganasan. Penatalaksanaan atelektasis meliputi pemberian antibiotik, fisioterapi dinding dada, humidifikasi dan hidrasi. ${ }^{32}$

Efusi pleura merupakan akumulasi cairan yang bertambah pada ruang pleura antara lapisan pleura parietal dan pleura viseral paru. ${ }^{33,34}$ Pada orang sehat hanya terdapat $5-10 \mathrm{ml}$ cairan serous di ruang pleura yang disekresikan sekitar 0,01 $\mathrm{mL} / \mathrm{kg} / \mathrm{jam}$ oleh lapisan pleura parietal dan diabsorpsi kembali oleh aliran limfatik lapisan pleura parietal. ${ }^{33}$ Beberapa mililiter cairan di ruang pleura berfungsi sebagai cairan lubrikasi antara 2 lapisan pleura. Efusi pleura dapat terjadi oleh beberapa mekanisme seperti peningkatan produksi cairan pleura, penurunan absorpsi cairan akibat perubahan tekanan hidrostatik kapiler, perubahan tekanan osmotik koloid dan adanya tekanan negatif intratorak. Mekanisme timbulnya efusi pleura tersebut disebabkan oleh beberapa penyakit yang mendasarinya seperti penyakit jantung, penyakit ginjal, penyakit hati, infeksi paru, trauma torak dan lain-lain. Infeksi paru dapat disebabkan oleh penyakit tuberkulosis, pneumonia, parasit dan virus. ${ }^{34}$

Torasentesis dilakukan bila terdapat keraguan pada efusi pleura yang tidak diketahui penyakit yang mendasarinya, dengan torasentesis cairan pleura dapat dibedakan antara transudat dan eksudat. ${ }^{33,34}$ Gangguan jantung dan hepar merupakan penyebab tersering timbulnya cairan transudat, sedangkan cairan eksudat tersering disebabkan karena pneumonia, emboli pulmonal, penyakit gastrointestinal dan keganasan paru. Gejala klinis efusi pleura diantaranya sesak nafas, nyeri dada, batuk, demam, menggigil dan penurunan berat badan. Gejala klinis dan pemeriksaan fisik pada pasien efusi pleura terkadang tidak ada atau normal bila akumulasi cairan pleura kurang dari $300 \mathrm{~mL}$, dan apabila pada pemeriksaan fisik tidak ditemukan penurunan fungsi respirasi dan dinding torak yang normal, jarang sekali efusi pleura berkembang menjadi keadaan yang hipoksemia. ${ }^{33}$

Penatalaksanaan efusi pleura yaitu dengan mengeluarkan cairan dari ruang pleura, kemudian tatalaksana terhadap penyakit yang mendasarinya. Penatalaksanaan pertama yaitu dengan membedakan antara cairan transudat atau eksudat. Berdasarkan klasifikasi Light dan Rodriguez yang dikutip dari $\mathrm{Yu}$ efusi pleura dibedakan berdasarkan jumlah cairan, warna dan parameter biokimia sebagai langkah awal pemberian terapi. Menurut Light dan Rodriguez, cairan transudat disebut dengan efusi tidak komplikasi dapat diberikan terapi konservatif atau dengan antibiotik, sedangkan cairan eksudat disebut dengan efusi dengan komplikasi dapat dilakukan torasentesis terapeutik, drainase dengan selang kateter, terapi fibrinolitik, pleurodesis dan tindakan bedah. ${ }^{33}$

\section{LAPORAN KASUS} KASUS 1

Seorang anak laki-laki, berusia 6 tahun datang ke Instalasi Gawat Darurat (IGD) RSUP. dr. M. Djamil, Padang pada tanggal 4 Oktober 2013, jam 12.00 WIB dengan keluhan utama tersedak paku yang ditemukan saat bermain bersama temannya sejak 3 hari, awalnya pasien menggigit paku kertas, tiba-tiba pasien tersedak paku saat tertawa dengan temannya. Pasien batuk-batuk, sesak nafas dan kebiruan saat kejadian. Saat datang pasien masih mengeluh agak sesak nafas disertai batukbatuk. Nyeri dileher dan dada tidak ada, mual dan muntah tidak ada, demam dan pilek tidak ada, pasien masih bisa makan dan minum seperti biasa. Riwayat batuk-batuk lama, sesak nafas dan asma sebelumnya tidak ada, riwayat kontak dengan penderita batuk- 
batuk lama tidak ada, batuk darah tidak ada, Riwayat persalinan spontan dengan bidan, menangis kuat, berat badan lahir 2800 gr, cukup bulan dengan riwayat imunisasi dasar lengkap. Kemudian pasien berobat ke RSUD setempat dan dirujuk ke RSUP. dr. M. Djamil, Padang.

Pada pemeriksaan fisik keadaan umum baik, komposmentis, frekuensi nafas $30 \mathrm{x} /$ menit, sianosis $(-)$, berat badan $14 \mathrm{~kg}$. Pada pemeriksaan fisik regio torak, inspeksi; retraksi (-), auskultasi; stridor (-), wheezing (-/-), ronkhi (-/-), suara nafas paru kanan berkurang dibandingkan paru kiri. Pemeriksaan fisik lokali telinga, hidung dan tenggorok dalam batas normal, pemeriksaan laringoskopi indirek tidak dapat dilakukan karena pasien tidak kooperatif. Kemudian pasien didiagnosis dengan "suspek benda asing (paku) di saluran nafas"

Pada tanggal 4 Oktober 2013 dilakukan pemeriksaan Rontgen servikal-torakal anteroposterior dan lateral didapatkan kesan "adanya gambaran radiopak dengan proyeksi bronkus kanan setinggi torakal 5-6, tampak trakea tertarik kekanan, tampak perselubungan semiopak, batas tegas sesuai dengan segmen apikal lobus superior dan lobus inferior paru kanan. Tampak infiltrate di suprahiler serta perikardial bilateral, sinus dan diafragma kanan tertutup perselubungan". Kemudian pasien didiagnosis dengan "benda asing (paku) di bronkus kanan dengan suspek efusi pleura kanan, atelektasis paru kanan dan pneumonia aspirasi”.(Gambar 1 dan 2)

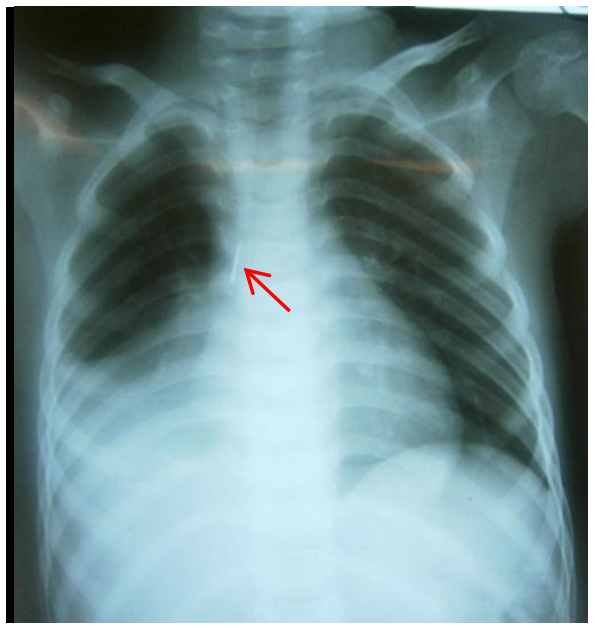

Gambar 1. Rontgen foto polos serviko-torakal posisi anteroposterior (kasus 1)

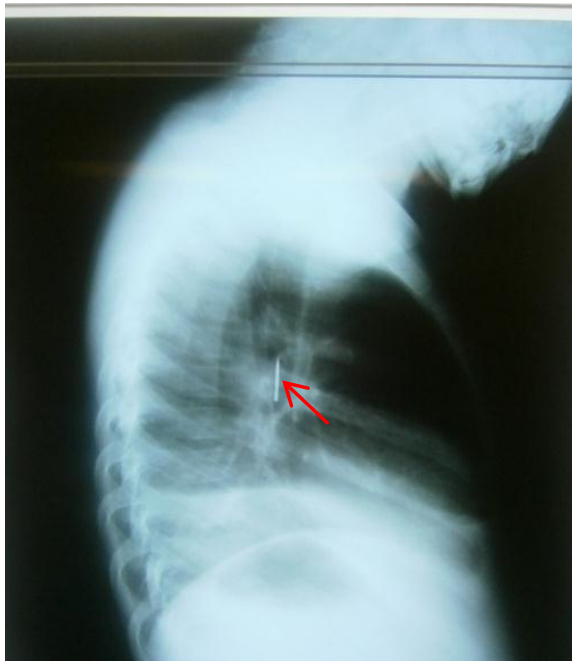

Gambar 2. Rontgen foto polos serviko-torakal posisi lateral

Pasien dipersiapkan untuk dilakukan tindakan bronkoskopi kaku dan ekstraksi benda asing dalam anastesi umum. Dilakukan informed consent kepada keluarga untuk tindakan bronkoskopi dan keluarga setuju, pemeriksaan laboratorium darah dan pasien dikonsulkan ke bagian IImu Kesehatan Anak untuk toleransi operasi dan rawat bersama dengan bagian anak pasca operasi.

Pada tanggal 4 Oktober 2013 dilakukan pemeriksaan laboratorium dan didapatkan hemoglobin $11,2 \mathrm{~g} / \mathrm{dl}$, hematokrit $34 \%$, leukosit 17.600/ $\mathrm{mm}^{3}$,trombosit 375.000/mm, PT (Protrombin Time) 11,1 detik dan APTT (Anti Platelet Trombin Time) 36,3 detik. Pemeriksaan analisa gas darah didapatkan $\mathrm{PH} 7,31$, pCO2 $40 \mathrm{mmHg}$, pO2 $15 \mathrm{mmHg}$, HCO3 20,1 mmol/L, CO2 21,3 $\mathrm{mmol} / \mathrm{L}, \quad$ BE 5,0 $\mathrm{mmol} / \mathrm{L}$.

Sebelum operasi, pasien diberikan terapi oleh bagian kesehatan anak dengan amoksisilin $3 \times 375 \mathrm{mg}$ (iv), kloramfenikol 4x275 mg (iv) dan deksametason $7 \mathrm{mg}$ (iv) dosis awal sebelum operasi dan dilanjutkan deksametason $3 \times 2,5 \mathrm{mg}$ (iv) sebagai dosis pemeliharan. Sebelum operasi dilakukan segera Rontgen ulang serviko-torakal anteroposterior dan didapatkan kesan "posisi benda asing (paku) di bronkus kanan tetap sama dengan gambaran sebelumnya disertai suspek efusi pleura kanan, atelektasis paru kanan dan pneumonia aspirasi"

Pada tanggal 4 Oktober 2013 jam 20.00 
WIB, pasien dilakukan bronkoskopi kaku dalam anastesi umum. Laporan operasi, pasien tidur terlentang di meja operasi dalam anastesi umum, dilakukan tindakan aseptik dan antiseptik, kemudian dimasukkan bronkoskop kaku ukuran diameter $4 \mathrm{~mm}$ panjang $30 \mathrm{~cm}$. Bronkoskop dimasukan dengan bantuan laringoskop Miller, trakea ditelusuri hingga terlihat karina kemudian diarahkan ke bronkus utama kanan. Terlihat benda asing di bronkus utama kanan dengan posisi arah yang tajam menghadap proksimal dan ujung tumpul menghadap ke distal. Kemudian dilakukan ekstraksi benda asing dengan menggunakan cunam alligator. Benda asing berupa paku kertas dengan panjang 2,2 cm berhasil dikeluarkan bersamaan dengan bronkoskop. (Gambar

3) Selanjutnya bronkoskop kembali dimasukkan untuk evaluasi mukosa trakea sampai bronkus kanan. Pada bronkus kanan terlihat penumpukan sekret mukopurulen, kemudian dilakukan pengisapan sekret kurang lebih $15 \mathrm{cc}$ dan dilakukan bronchial washing pada bronkus kanan. Evaluasi mukosa bronkus kanan tampak hiperemis, jaringan granulasi tidak ada, ekskoriasi dan laserasi tidak ada, edema serta perdarahan tidak ada. Bronkoskop ditarik keluar secara perlahan, operasi selesai.

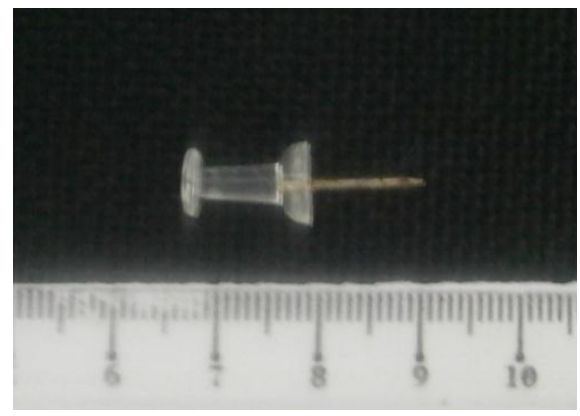

Gambar 3. Benda asing (paku kertas) di bronkus kanan pasca ekstraksi

Pasca operasi pasien didiagnosis dengan "pasca bronkoskopi dan ekstraksi benda asing (paku kertas) di bronkus kanan dengan suspek efusi pleura kanan, atelektasis paru kanan dan pneumonia aspirasi". Pasien diberikan terapi amoksisilin $3 \times 375 \mathrm{mg}$ (iv), kloramfenikol 4x275 mg (iv) dan deksametason $3 \times 2,5 \mathrm{mg}$ (iv).

Follow up (hari pertama pasca operasi) tanggal 5 Oktober 2013, pasien masih mengeluh batuk-batuk, sedikit sesak nafas, batuk darah tidak ada, suara serak dan demam tidak ada. Pada pemeriksaan fisik keadaan umum baik, frekuensi nafas $28 \mathrm{x} /$ menit, sianosis (-) dan tanda vital lainnya dalam batas normal. Pada pemeriksaan regio torak, inspeksi; retraksi (-), palpasi regio colli dan torak krepitasi dan nyeri tekan tidak ada, pada auskultasi; stridor (-), wheezing (-/-), ronkhi (-/-), suara nafas paru kanan vesikuler lemah. Pemeriksaan lokalis THT-KL pada telinga, hidung dan tenggorok dalam batas normal. Kemudian dilakukan pemeriksaan Rontgen serviko-torakal posisi anteroposterior dan lateral ulang pasca bronkoskopi dan didapatkan kesan " Tidak terlihat gambaran radiopak, trakea tertarik kekanan, terlihat perselubungan semiopak, batas tegas sesuai dengan segmen apikal lobus superior dan lobus inferior paru kanan. Tampak infiltrat di suprahiler serta perikardial bilateral, sinus dan diafragma kanan tertutup perselubungan". (gambar 4).

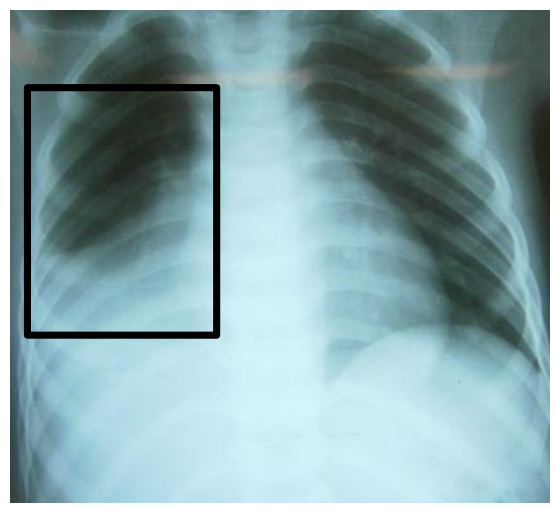

Gambar 4. Rontgen foto polos serviko-torakal posisi anteroposterior dan lateral pasca bronkoskopi (kasus 1)

Dari Bagian IImu Kesehatan Anak direncanakan untuk dilakukan torasentesis, tetapi keluarga pasien menolak untuk tindakan tersebut.

Follow up (hari kedua pasca operasi) tanggal 6 Oktober 2013, pasien tidak mengeluh batuk-batuk, sesak nafas tidak ada, batuk darah tidak ada, suara serak dan demam tidak ada. Pada pemeriksaan fisik keadaan umum baik, sianosis (-), frekuensi nafas $24 x /$ menit dan tanda vital lainnya dalam batas normal. Pada pemeriksaan regio torak, inspeksi; retraksi (-), palpasi regio colli dan torak; krepitasi (-), nyeri tekan $(-)$, auskultasi; stridor (-), wheezing (-/-), ronkhi (-/-), suara nafas paru kanan vesikuler lemah. Pemeriksaan lokalis telinga, hidung dan tenggorok dalam batas normal. Pada saat dirawat, keluarga 
pasien meminta pulang paksa dengan alasan tidak ada lagi keluhan dari pasien.

\section{KASUS 2}

Seorang perempuan berusia 14 tahun datang ke Instalasi Gawat Darurat (IGD) RSUP.dr.M.Djamil, Padang pada tanggal 14 November 2013, jam 11.00 WIB dengan keluhan utama tersedak jarum pentul yang digigitnya saat menggunakan jilbab sejak 12 hari sebelum masuk rumah sakit. Pasien mengeluh batuk-batuk, nyeri di dada tidak ada, nyeri di leher tidak ada, sesak nafas tidak ada, batuk darah tidak ada, suara serak tidak ada. Pasien masih bisa makan dan minum seperti biasa, air liur mengumpul dimulut tidak ada, mual dan muntah tidak ada, serta riwayat demam selama 12 hari tidak ada.

Pada pemeriksaan fisik keadaan umum baik, komposmentis kooperatif, sianosis (-), frekuensi nafas 20x/menit dan tanda vital lainnya dalam batas normal. Pada pemeriksaan dada, inspeksi; retraksi (-), auskultasi; stridor (-), wheezing (-/-), ronkhi (-/-), suara nafas paru kanan dan kiri sama vesikuler. Pemeriksaan fisik lokalis THT-KL pada telinga, hidung dan tenggorok dalam batas normal, pemeriksaan laringoskopi indirek dalam batas pormal. Pasien didiagnosis dengan suspek benda asing (jarum pentul) di saluran nafas.

Pada tanggal 14 November 2013 dilakukan pemeriksaan radiologi Rontgen servikal-torakal anteroposterior dan lateral didapatkan kesan "adanya gambaran radiopak setinggi servikal 7-torakal 4 . (Gambar 5 dan 6) Pasien didiagnosis dengan benda asing (jarum pentul) di trakea.

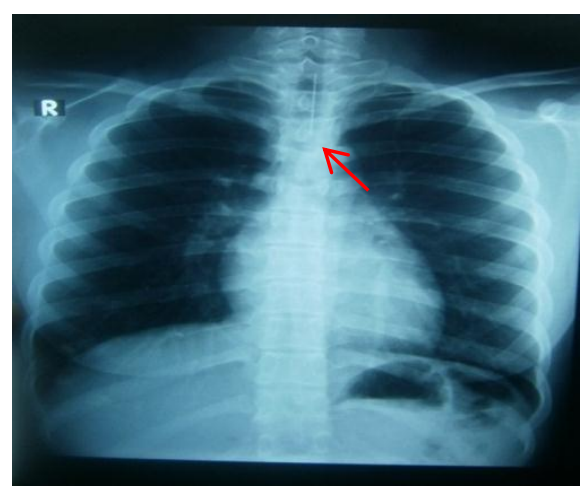

Gambar 5. Rontgen foto polos serviko-torakal posisi anteroposterior (kasus 2)

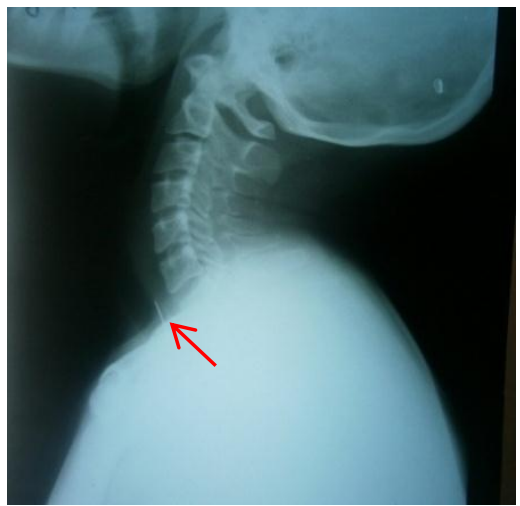

Gambar 6. Rontgen foto polos serviko-torakal posisi lateral (kasus 2)

Pasien dipersiapkan untuk dilakukan tindakan bronkoskopi kaku dan ekstraksi benda asing dalam anastesi umum. Dilakukan informed consent kepada pasien untuk tindakan bronkoskopi dan pasien setuju, kemudian pada tanggal 14 November 2013 dilakukan pemeriksaan laboratorium darah, didapatkan hasil laboratorium hemoglobin $13,9 \mathrm{~g} / \mathrm{dl}$, hematokrit $42 \%$, leukosit $11.100 / \mathrm{mm}^{3}$, trombosit 345.000/ $\mathrm{mm}^{3}$, РT(Protrombin Time) 10,4 detik dan APTT (Anti Platelet Trombin Time) 37,4 detik. Sebelum operasi, pasien diberikan terapi seftriakson $2 \times 1$ gr (iv), deksametason $3 \times 5 \mathrm{mg}$ (iv). Sebelum operasi segera dilakukan Rontgen ulang servikotorakal anteroposterior dan didapatkan gambaran posisi benda asing (jarum pentul) ditrakea tidak berubah posisi dibandingkan dengan Rontgen sebelumnya.

Pada tanggal 14 November 2013, jam 16.00 WIB, dilakukan bronkoskopi kaku dalam anastesi umum. Laporan operasi, pasien tidur terlentang di meja operasi dalam anastesi umum, dilakukan tindakan aseptik dan antiseptik, kemudian dimasukkan bronkoskop kaku ukuran diameter $6 \mathrm{~mm}$ panjang $30 \mathrm{~cm}$. Bronkoskop dimasukan dengan bantuan laringoskop Miller melewati rima glotis, bronkoskop dimasukkan ke trakea sampai karina. Terlihat benda asing dengan posisi arah ujung lancip menghadap proksimal menancap di mukosa karina dan ujung tumpul menghadap di distal bronkus utama kanan. Kemudian dilakukan ekstraksi benda asing menggunakan alligator forcep dengan berbagai manuver untuk melepaskan ujung jarum pentul yang tertancap pada mukosa karina. Benda asing (jarum 
pentul) dengan panjang $3,7 \mathrm{~cm}$ berhasil dikeluarkan.

(Gambar 7)

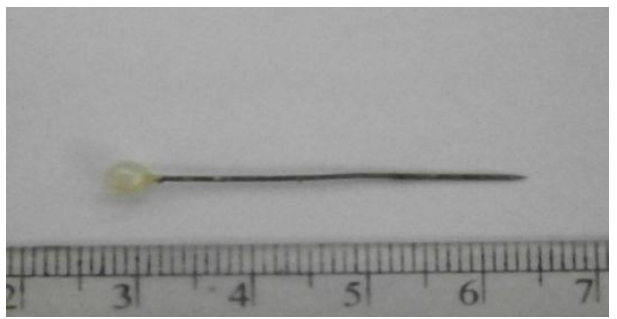

Gambar 7. Benda asing (jarum pentul) di bronkus kanan pasca ekstraksi

Kemudian dilakukan evaluasi mukosa trakea, karina sampai bronkus kanan. Terlihat punctum pada mukosa karina, edema tidak ada, ekskoriasi, laserasi dan perdarahan aktif tidak ada. Bronkoskop ditarik keluar secara perlahan, operasi selesai. Pasca operasi pasien didiagnosis benda asing (jarum pentul) di bronkus kanan. Pasca operasi diberikan terapi seftriakson 2x1 gr (iv), deksametason $3 \times 5 \mathrm{mg}$ (iv) dan tramadol 1 ampul/kolf/8 jam (drip iv).

Follow up hari pertama pasca bronkoskopi pada tanggal 15 November 2013, pasien masih mengeluh nyeri dada dan batuk-batuk, batuk darah tidak ada, sesak nafas, suara serak maupun demam tidak ada. Pada pemeriksaan fisik keadaan umum baik, sianosis tidak ada, frekuensi nafas 20x/menit dan tanda vital lainnya dalam batas normal. Pada pemeriksaan inspeksi regio torak; retraksi (-), palpasi regio colli dan torak; krepitasi (-), nyeri tekan (-), pada auskultasi; stridor (-), wheezing (-/-), ronkhi (-/-), suara nafas paru kanan dan kiri sama vesikuler. Pemeriksaan lokalis THT-KL pada telinga, hidung, tenggorok dan laringoskopi indirek dalam batas pormal. Kemudian dilakukan pemeriksaan Rontgen polos serviko-torakal posisi anteroposterior dan lateral ulang pasca bronkoskopi didapatkan kesan jantung dan paru dalam batas normal.(gambar 8).

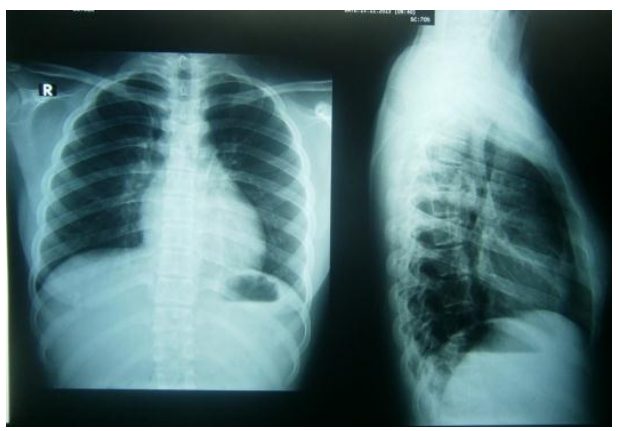

Gambar 8. Rontgen foto polos serviko-torakal posisi anteroposterior dan lateral pasca bronkoskopi (kasus2)

Follow up hari kelima pasca bronkoskopi pada tanggal 19 November 2013 pasien masih mengeluh kadang-kadang batuk, demam tidak ada, nyeri dada maupun sesak nafas tidak ada. Pada pemeriksaan fisik umum dan lokalis THT-KL dalam batas normal, pasien dipulangkan dan diberikan terapi sefiksim $2 \times 100 \mathrm{mg}$, ambroksol $3 \times 30 \mathrm{mg}$ oral dan dianjurkan untuk kontrol ke poliklinik THT-KL. Pada tanggal 25 November 2013, pasien datang kontrol ke poliklinik THT-KL, pasien tidak mengeluh batuk-batuk, sesak nafas tidak ada dan demam tidak ada. Pada pemeriksaan fisik umum maupun lokalis THT dalam batas normal, kemudian pasien dipulangkan dan dianjurkan kontrol bila ada keluhan.

\section{DISKUSI}

Telah dilaporkan dua kasus aspirasi benda asing tajam yaitu anak laki-laki, berumur 6 tahun yang didiagnosis dengan aspirasi paku di bronkus utama kanan dengan komplikasi atelektasis paru dan seorang perempuan dewasa muda berjilbab berumur 14 tahun dengan aspirasi jarum pentul di bronkus utama kanan tanpa komplikasi. Benda asing harus diketahui berdasarkan jenis, bentuk, ukuran, dan lokasi dari benda asing disaluran nafas. Pada kedua kasus ini terjadi aspirasi benda asing anorganik tajam 
dengan lokasi pada bronkus kanan.

Salah MT $\mathrm{dkk}^{35}$ pada penelitiannya mendapatkan presentase lokasi benda asing yaitu hipofaring (5\%), laring/trakea (12\%) dan yang tersering di bronkus (83\%). Bronkus utama kanan merupakan terbanyak yaitu (43\%), bronkus utama kiri (24\%), segmen bronkus kanan (22\%) dan segmen bronkus kiri (11\%). Sarraf NA dkk ${ }^{28}$ pada penelitian Januari 1996- Desember 2008 melaporkan sebanyak 35 kasus aspirasi jarum pentul dari 48 kasus benda asing tajam di trakeobronkial pada wanita yang sering meletakkan jarum pentul diantara bibir sebelum memasang jilbabnya. Predisposisi aspirasi jarum pentul pada wanita muslim yang menggunakan jilbab terjadi saat tertawa, berbicara dan terbatuk.

Pada kedua kasus didapatkan riwayat tersedak benda asing yang disertai batuk-batuk, sesak nafas dan kebiruan saat kejadian. Anamnesis yang baik mengenai adanya riwayat tersedak atau kemungkinan tersedak sangat membantu dalam menegakkan diagnosis. Terkadang orang tua tidak mengetahui bahwa anaknya tersedak. Seorang anak yang sedang bermain tiba-tiba batuk, sesak nafas, nafas berbunyi dan sianosis maka harus dicurigai tersedak benda asing. Anamnesis yang kurang baik dapat menimbulkan kesalahan diagnosis, sehingga tidak jarang penderita diberi pengobatan untuk panyakit lain, misalnya asma atau peumonia. Pneumonia berulang merupakan komplikasi akibat benda asing untuk waktu yang lama. Adanya trias batuk, mengi dan sesak nafas pada anak-anak tanpa riwayat asma sebelumnya, perlu dicurigai aspirasi benda asing. ${ }^{15,16}$

Pada kasus pertama, pasien datang dalam fase komplikasi yaitu terjadinya atelektasis paru akibat aspirasi benda asing. Berdasarkan anamnesis didapatkan adanya sesak nafas dan batuk-batuk, pada pemeriksaan auskultasi didapatkan suara nafas paru kanan melemah. Pada pemeriksaan radiologi torak didapatkan kesan atelektasis paru kanan akibat benda asing pada bronkus kanan serta adanya pneumonia aspirasi.

Pada kasus kedua, pasien masuk dalam fase asimtomatik yaitu fase dimana pasien masih dalam keadaan umum yang baik. Fase asimptomatik dapat terjadi dari beberapa menit sampai berbulan- bulan setelah fase pertama. Lama fase ini tergantung lokasi benda asing, derajat obstruksi yang ditimbulkan, ukuran dan jenis benda asing yang teraspirasi. ${ }^{13,19}$

Diagnosis aspirasi benda asing selain berdasarkan anamnesis dan gejala klinis dibutuhkan juga pemeriksaan radiologi. Pada pemeriksaan radiologi kasus aspirasi benda asing dapat ditemukan gambaran benda asing yang radioopak dan sering didapatkan adanya gambaran infeksi paru, udara yang terperangkap dan atelektasis pada aspirasi benda asing lama. Sekitar 24\% pasien yang dilakukan pemeriksaan radiologi tidak menunjukkan kelainan paru walupun sudah dilakukan bronkoskopi. ${ }^{31}$ Pada kedua kasus benda asing paku dan jarum pentul ini mudah didiagnosis dengan menggunakan Rontgen foto torak karena benda asing berasal dari logam sehingga gambaran radiologi berupa gambaran radioopak.

Komplikasi aspirasi benda asing di trakeobronkial tergantung dari jenis, bentuk, ukuran dan posisi benda asing. Obstruksi total atau parsial dari bagian segmen bronkus dapat menyebabkan gangguan pertukaran udara didalam paru.9,31 Komplikasi akibat benda asing, dapat berupa pneumonia, efusi pleura, atelektasis, bronkiektasis, abses, pneumotorak dan hemoptisis. ${ }^{13,19,31}$. Pada penelitian Cassol $\mathrm{dkk}^{36}$ mendapatkan $80 \%$ gambaran radiologi komplikasi benda asing disaluran nafas pada anak-anak adalah atelektasis dan pneumonia sekunder.

Pada kasus pertama didapatkan gambaran radiopak benda asing, atelektasis paru kanan dan adanya pneumonia aspirasi, sedangkan pada kasus kedua pada pemeriksaan radiologi tidak menunjukkan adanya kelainan paru akibat benda asing. Timbulnya atelektasis pada kasus pertama kemungkinan disebabkan adanya sumbatan total pada bronkus utama kanan akibat ukuran diameter bagian distal benda asing hampir sama dengan ukuran diameter lumen bronkus utama kanan pada anak-anak, sehingga pertukaran udara dalam paru terganggu, sedangkan kemungkinan kompresi parenkim paru akibat peningkatan tekanan intratorak oleh efusi pleura belum dapat disingkirkan, dikarenakan pasien menolak untuk dilakukan torasentesis. Pada kasus 
kedua ukuran benda asing jarum pentul tidak menyebabkan obstruksi pada segmen paru karena ukuran diameter ujung proksimal maupun distal benda asing lebih kecil dibandingkan dengan ukuran lumen bronkus kanan, sehingga aliran udara pada paru tidak terganggu.

Rontgen foto torak ulang satu jam sebelum tindakan bertujuan untuk mengetahui perubahan letak benda asing. Benda asing radiopak masih mungkin untuk berpindah letak karena ukurannya kecil serta permukaan yang licin. ${ }^{23}$ Pemeriksaan laboratorium darah diperlukan untuk mengetahui adanya gangguan keseimbangan asam basa serta adanya tanda infeksi trakeobronkial. ${ }^{19}$ Pada kasus pertama dilakukan pemeriksaan analisa gas darah karena pasien sesak sedangkan pada kasus kedua tidak dilakukan pemeriksaan analisa gas darah karena pasien tidak sesak. Pada kasus pertama didapatkan kadar leukosit yang meningkat secara signifikan akibat telah terjadi komplikasi infeksi paru sedangkan pada kasus kedua kadar leukosit tidak meningkat secara signifikan karena belum terjadi komplikasi.

Ketika tampak benda asing radiopak tajam dengan Rontgen foto torak harus segera dikeluarkan dengan bronkoskopi kaku maupun fleksibel. ${ }^{8,12}$ Bronkoskop kaku dipilih dengan pertimbangan pernafasan lebih terkontrol, oksigenasi adekuat, lumen lebih besar sehingga memudahkan melakukan tindakan ekstraksi serta dapat mengatasi perdarahan. 5,12,29 Pada penggunaan bronkoskop kaku, ujung runcing benda asing tajam harus diambil dan diletakkan ke dalam bronkoskop karena ujung runcing benda asing dapat membahayakan mukosa bronkus atau dinding bronkus. , $12^{2}$ Selain itu digunakan bronkoskop kaku pada anak karena bronkoskop kaku dapat di lakukan hisapan (suction) jalan nafas yang lebih efisien untuk kasus-kasus perdarahan masif, adanya penumpukan sekret dan bronkoskopi lavage. 12,28 Jika dibandingkan dengan bronkoskop kaku kekurangan bronkoskop fleksibel adalah pernafasan kurang terkontrol, dan lumen terlalu kecil untuk bisa memasukkan benda asing. 5,12,29

Pada kedua kasus ini digunakan bronkoskop kaku untuk ekstraksi benda asing tajam dengan meletakkan ujung runcing kedalam bronkoskop untuk melindungi mukosa bronkus. Pada kasus pertama terdapat penumpukan sekret pada bronkus kanan setelah benda asing berhasil diekstraksi, kemudian melalui bronkoskop kaku dilakukan penghisapan sekret dan bronchial washing pada bronkus kanan.

Menurut Lukomsky yang dikutip dari Mangape $\mathrm{dkk}^{8}$ bahwa komplikasi tindakan bronkoskopi terbagi 2 : a). Komplikasi minor berupa perlukaan mukosa faring, laringitis akut, hipoksia, perdarahan sedang dan demam. b). Komplikasi mayor berupa tension pneumothorak, perdarahan hebat, hipoksia berat sampai kegagalan jantung. Sedangkan menurut Cassol $\mathrm{dkk}^{36}$ komplikasi akibat tindakan bronkoskopi terbagi menjadi dua, yaitu: 1) Komplikasi minor, seperti adanya desaturasi oksigen dan 2). Komplikasi mayor seperti laringospasme dengan desaturasi, laringospasme dengan bradikardi, laringobronkospasme dengan bradikardi dan pneumotorak bilateral. Rontgen foto torak ulang pasca operasi perlu dilakukan untuk menilai jaringan submukosa longgar pada daerah subglotis yang dapat memberikan reaksi terhadap trauma kecil. ${ }^{8}$

Pada kedua kasus ini tidak terdapat komplikasi berat saat dilakukan tindakan bronkoskopi. Pasca operasi kedua kasus ini dilakukan Rontgen foto torak ulang dan tidak ditemukan adanya komplikasi akibat tindakan, baik yang tampak pada gambaran radiologi, maupun dari gejala klinis.

Kesimpulan dari kedua kasus ini, bahwa timbulnya komplikasi aspirasi benda asing pada saluran nafas tergantung pada jenis, ukuran, bentuk dan posisi benda asing pada saluran nafas. Waktu munculnya komplikasi tergantung dari derajat atau tipe obstruksi yang ditimbulkan oleh benda asing teraspirasi. Tipe obstruksi total dari benda asing terhadap lumen saluran nafas menyebabkan kolapsnya jaringan paru.

\section{DAFTAR PUSTAKA}

1. Brkic F, Umihanic S. Tracheobronchial foreign bodies in children experience at ORL clinic Tuzla, 1954-2004. Inter J of Ped Otol. 2007; 71: $909-15$ 
2. Iskandar N. Ingested and inhaled foreign bodies .In Dr. Cipto Mangunkusumo Hospital, Jakarta, Indonesia. Med J ORLI. 1994; 25: 311-8.

3. Latifi X, Mustafa A, Hysena Q. Rigid tracheobronchial in the management of airway foreign bodies: 10 years experience in Kosovo. Inter J of Ped otolaryngology. 2006; 70: 2055-9

4. Rina $M$, Quintos TR. Pediatric rigid bronchoscopy for foreign body removal. Philippine journal of Otolaryngology Head and Neck Surgery. 2009; 24: 39-41

5. Doody DP. Foreign body aspiration. In Grillo $\mathrm{HC}$ editors. Surgery of the trachea and bronchi. London: BC Decker Inc. 2004. p707-17

6. Cataneo AJM, Cataneo DC, Ruiz RL. Management of tracheobronchial foreign body in children. Pediatric Surgery Int. 2008; 24: 151-6.

7. Chandra D, Samiadi D. Benda Asing pada Bronkus. Kumpulan Makalah seminar Pertemuan IImiah Tahunan PERHATI. Batu Malang. 1996: 201-515.

8. Mangape D, Asbudi. Bronkoskopi kaku. Dalam: Lokakarya Endoskopi, Ujungpandang. Desember. 1987.

9. Taksande A, VilhekarK, Tyyagi V. Uncommon Foreign Body Aspiration in Infant. Calicut Med Journal. 2010;8(2):1-3

10. Asif M, Shah SA, Khan F, Ghani R. Foreign body inhalation - site of impaction and efficacy of rigid bronchoscopy. J Ayub Med Coll abbottabad. 2007; 19: 46-8.

11. David E. Eibling, Management of intractable aspiration. In: Byron J.Bailey \& Jonas T.Johnson editors, Head \& Neck Surgery otolaryngology. $1998 \mathrm{ed} .4^{\text {th }}$. p 733-43.

12. Sarraf NA, Eddine HJ, Khaja F, Aed AK. Headscraf pin tracheobronchial aspiration. In.Interactive Cardivascular and Thoracic Surgery. (2009):187-90.

13. Rose M.Mohr, M.D, Foreign Body Tracheobronchial tree. Paparella shumrick. In: Otolaryngology head and neck volume III. 1998 , ed. $4^{\text {th }}$. p 2399-424.
14. Leighton G.Siegel,M.D, Penyakit jalan nafas bagian bawah dan mediastinum: pertimbangan Endoskopi. In: Adam boies higher buku ajar penyakit THT. 1997, edisi 6. p 454-72.

15. Ravindhra G.Elluru, Endoscopy of the pharynx and esophagus, in: Cummings otolaryngology Head \& neck surgery. 1998 , ed. $4^{\text {th }} \quad p 1825-$ 34.

16. Gibson SE. Aerodigestive Tract Foreign Body. In : Catton RT et al. Practical Ped Otolaryngol. Philadelphia: lippincott- Raven,1999:561-73.

17. Munter DW. Foreign Bodies Trachea. Available from: www.emedicine.com, last updated august 26, 2009.

18. Warshawsky ME. Foreign Body Aspiration. Available from: www.emedicine.com, last updated August 20, 2004.

19. Junizaf MH. Benda Asing di Saluran Napas. Dalam: Soepardi EA, Iskandar N, editors. Buku Ajar IImu Kesehatan THT-Kepala Leher Jakarta: Balai Penerbit FKUI ; 2007. p 259-65.

20. Cosal ID, Imran Ali. Penggunaan bronkoskopi serat optik dalam diagnosis dan pengobatan kelainan trakeobronkial. Dalam: Lokakarya Endoskopi, Ujungpandang. Desember 1987.

21. Friedman EM. Caustic ingestion and foreign bodies in the aerodigestive tract. In : Bailey BJ, eds. Head and Neck Surgery-Otolaryngology, $3^{\text {rd }}$ ed vol 1. Philadelphia: Lippincott Williams \& Wilkins. 2004, 200: 1157-66.

22. Manukbua Anton, Andilolo M. Bronkoskopi kaku versus bronkoskopi serat optik. Dalam: Lokakarya Endoskopi, Ujung pandang. Desember 1987.

23. Kaur K, Sonkhya N, Bapna AS. Foreign bodies in the trcheobronchial : a prospective study of fifty cases. Indian $\mathrm{J}$ of Otolaryngology, Head and Neck Surgery. 2002; 54 (I): 30-4.

24. Tandra $\mathrm{AH}$, Ramli M. Anestesia dan analgesia pada tindakan endoskopi peroral. Dalam: Lokakarya Endoskopi, Ujung pandang. Desember 1987.

25. Perkasa MF. Ekstraksi benda asing di laring dengan neuroleptic anesthesia. Case report original artikel. 2009; 22: 20-3 
26. Kalyanappagol VT, kulkarni NH, Bidri LH. Management of tracheobronchial foreign body aspiration in pediatric age group- 10 year retrospective analysis. 2007; 51: 20-3.

27. Ripley DP, Henderson AK. A case of aspiration: the importance of early diagnosis and clinical suspicion. Primary care Resp Journal. 2007; 16: 191-3.

28. Wachid Mochamad, Sisantoro. Atelektasis Menetap Akibat Benda Asing Bronkus. Smf IImu Kesehatan Penyakit THT FK UNAIR. Surabaya: Media perhati. Vol 7; Juni 2001.

29. Jackson C. Bronchoesophagology. In: Bronchoesophagology. Philadelphia and London. 1958. p 5-34

30. Tjandrasusilo Handoko. Bronkoskop serat optik. Dalam: Lokakarya Endoskopi, Ujungpandang. Desember 1987.

31. Olieveira CF, Almeida JFL, Troster EJ, Costa Vaz FA. Complication of Tracheobronchial Foreign Body Aspiration in Children : Report of
5 Cases and Review of The Literature. Rev. Hosp. Clin. Fac. Med. S. Paulo. 2002; 57(3): 108-11

32. Raman TSR, Mathew S, Ravikumar, Garcha PS. Atelectasis in Children. Indian Pediatrics. 1998; Vol 35:429-35

33. $\mathrm{Yu} \mathrm{H}$. Management of Pleural Effusion, Empyema, and Lung Abscess. Semin Intervent Radiol. 2011; 28:75-86

34. Garrido VV, Sancho JF, Blasco H, Gafas AP, Rodriguez EP, Panadero FR et al. Diagnosis and Treatment of Pleural Effusion. Arch Bronconeumol. 2006;42(7):349-72

35. Salah MT, Hamza S, Murtada M, Salma M. Delayed diagnosis of foreign body aspiration in children. Sudanese Journal of Public Health: January 2007.Vol 2 (1):48-50

36. Cassol V, Pereira AM, Zorzela LM, Becker MM, Barreto SSM. Foreign Body in Children's Airways. J.Pneumologia. 2003; Vol 29:1-10 